\title{
Shoreline Change Detection from Cuddalore to Nagapattinam Coast, Tamil Nadu
}

\author{
Pradeep J, Aparna S. Bhaskar
}

\begin{abstract}
Erosion of shoreline areas is one of the major sources of problems on the world, whose impact has had a devastating effect on coastal communities. The coastal region of India is undergoing various natural and Anthro -pogenic process activities which controls the accretion, erosion rates along the coastal area. Existing research suggests that the merged use of satellite imagery and mathematical techniques are the appropriate technique for coastal survey analysis. The study was conducted in the Cuddalore to Nagapattinam coastal area till kodiyakarai (Tamil Nadu), India ,Using satellite -data imagery from 2003 to 2017. This coastal stretch has been report high rate of erosion as well as Accretion. Coastal side erosion and long-term erosion, accretion rates were calculated using DSAS, to measure the rate of change of the shoreline. Analysis results shows erosion is rampant in Mayiladuthurai district, Tharangambadi - Karaikal (Puducherry Union Territory) especially from Tharangambadi beach to nagore beach
\end{abstract}

Keywords: DSAS (Digital Shoreline Analysis System), Erosion, Accretion, Shoreline

\section{I.INTRODUCTION}

Coastal-shoreline erosion happens as a results due to results of tidals, seasonal changes occurring at sea level, hurricane-force winds and tsunamis, the coast often restores stability in a few months or years. permanent and unwanted coastal erosion is identified by a long-term study of coast line behavior. coastal areas, which comes under low-land areas are at high risk of erosion. Hurricanes and tsunamis are considered natural disasters, and man-made disasters are those caused by human activities such as air- pollution \& deforestation, leading to Global- warming, which in turn has resulted in melting glaciers, thus contributing to rising sea or coastal levels. Sea-level rise associated with human activity in the region at local scales cause significant coastal or shoreline erosion. Man made activity at the zonal level scale, such as construction of upstream dams in the stream basins is the primary source of cause in seaside or shoreline erosion particularly in deltaic-coast, as the significant origin of deposits of sediments is impounded at dam site areas, depriving the seaside( zones) of coast especially for deltabuilding (Day et al., 1995; Warne \&Stanley).

Manuscript received on September 17, 2021.

Revised Manuscript received on September 22, 2021.

Manuscript published on September 30, 2021

* Correspondence Author

Pradeep J, Student, Masters, Remote Sensing and GIS in SRM Institute of Science and Technology, Chennai (Tamil Nadu), India.

Dr. Aparna S., Bhaskar (Ph.D) Associate Professor, Department of Civil Engineering, Kattankulathur Campus, SRM Institute of Science and Technology, Chennai (Tamil Nadu), India.

(C) The Authors. Published by Blue Eyes Intelligence Engineering and Sciences Publication (BEIESP). This is an open access article under the CC BY-NC-ND license (http://creativecommons.org/licenses/by-nc-nd/4.0/)
On the local side, the construction of port structures such as groins, as well as seawall on shoreline completely disrupts the sediment-deposit routes ,that leads to accretion and erosion on the shores coast of such structures(WHOI,2000;) and the formation of coastal water changes the shoreline, causing erosion. Similarly, the excavation of sand in beaches, as well as the destruction of mangrove forests \& saltwater swamps is also leading to coastal erosion at the local level. The need of study is to identify erosion and accretion areas in Cuddalore to Nagapattinam District. Aim of the work is to detect the shoreline transition using multi shoreline data with statistical techniques (DSAS) during the time period from 2003-2017 along Cuddalore to Nagapattinam district till kodiyakarai coast.

\section{II.DATA METHODS AND STUDY AREA}

The data used in this study are LANDSAT 7 of 2003 to 2017 at a spatial resolution of $30 \mathrm{~m}$ and software's used in this study are Arc GIS 9.3 and DSAS (Digital Shoreline Analysis System). The study area extends between $11^{\circ} 77^{\prime} \mathrm{N}$ and $79^{\circ} 69^{\prime} \mathrm{E}$ to $10^{\circ} 74^{\prime} \mathrm{N}$ and $79^{\circ} 92^{\prime} \mathrm{E}$. The study area starts from the lower reaches of the Ponnaiyar River valley and Uppanar. The study area includes the areas of Cuddalore, Chidambaram (Pichavaram), Thiruvarur (Atiramapattinam) and Nagapattinam (Poompuhar, Velanganni) as well as part of Union territory of Pondicherry (Karaikal) Till kodiyakarai .The study area (fig 1) is well connected by roads and railway networks. The study area has significant economic benefits such as tourism, fishing \& aquaculture. Both areas are experiencing tropical storms, depressions in BOB(Bay of Bengal)during Northeast monsoon which affects the coastal or shoreline zones . Largeparts of the coastal area are Low-Lying especially in Chidambaram (Pichavaram) \& Cuddalore region in Southern India leading to major erosion. Coast line is most vulnerable \& most( prone) to Storms. Nagapattinam district, which includes sandy beaches along the coastal region and salt pans near Tirumullaivasal and Tharangambadi with the mangrove forest. Nagapattinam district is a plain terrain with slope less than one percent and Cuddalore district, a coastal plain with a range of [6 km] of land including mangrove swamps, raised beach and a completely flat-terrain with Dark \& Light sand, and the total area of the region is (3678 sq km) with a shore line of $36 \mathrm{~km}$ from Puducherry (pondicherry) North to Coleroon River in the south.
Published By:

Blue Eyes Intelligence Engineering and Sciences Publication (BEIESP)

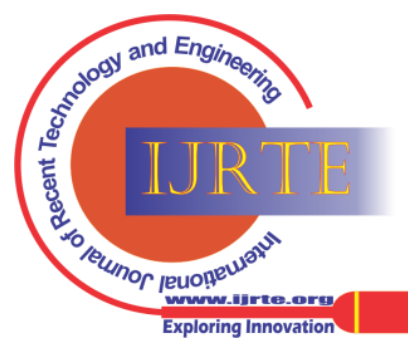




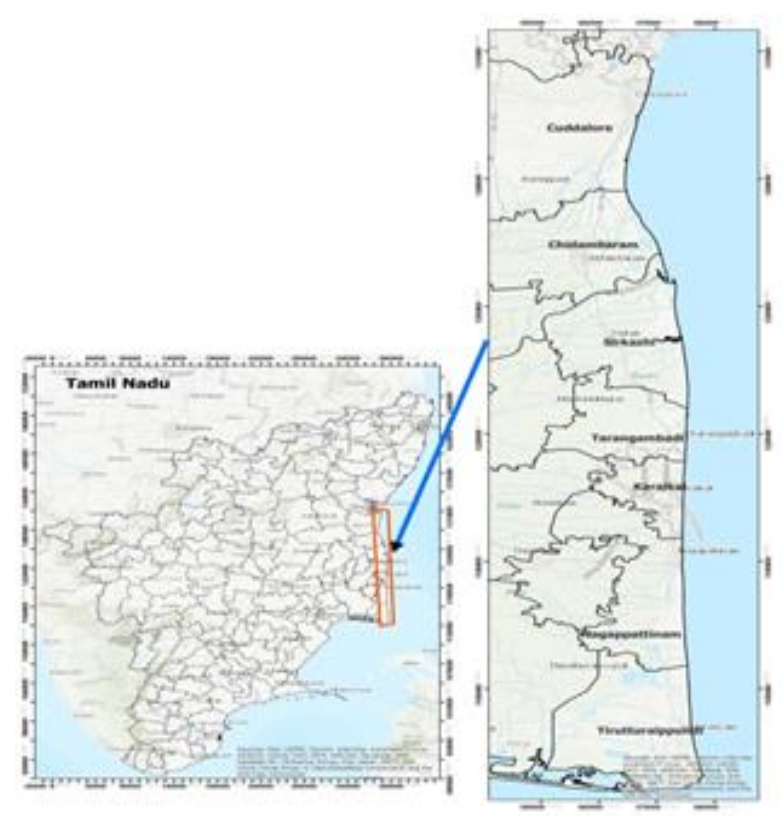

Fig.1 Study Area-Cuddalore to Nagapattinam

\section{METHODOLOGY}

Coastal shoreline analysis has carried out in the study to calculate the change of Coastal line shift in a time series of multiple coastal positions. satellite Data Products were obtained from USGS. Coastal studies of Cuddalore to Nagapattinam were studied for the period 2003 to 2017. Shorelines has been derived from satellite-data (2003-2017) using Arc GIS software version 9.3. Boundary of high tide water lines taken for the coast using manual extraction method, Time-interval in coastal position was created in ENVI software for the years 2003,2017 Shoreline was drawn by digitization using visual rendering technique using Arc GIS software version 9.3. Input shorelines are used as input to the DSAS(digital shoreline analysis system). Shorelines are redirected as structure formats added to individual files and drifts in to Geodatabase with an Arc catalog.

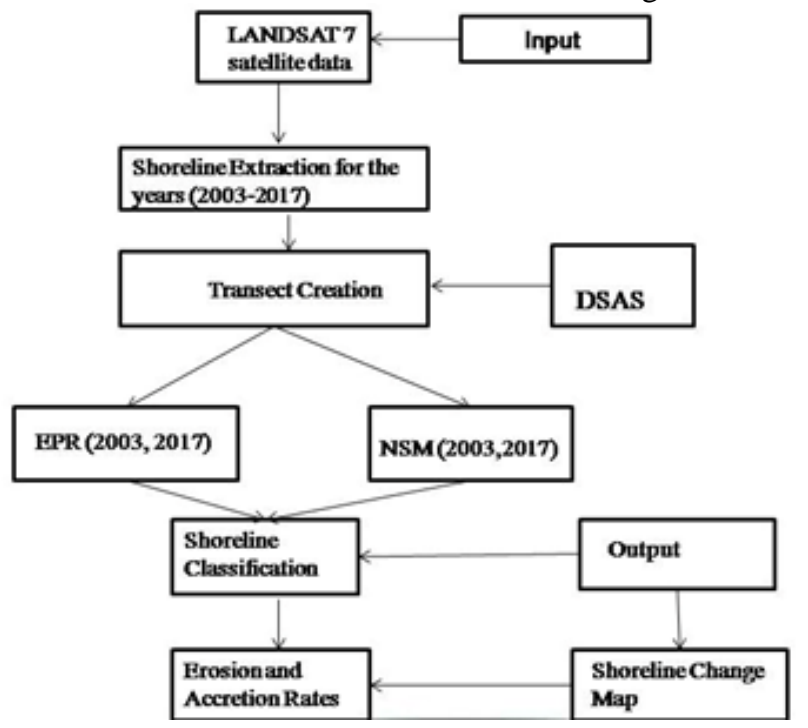

.Fig .2 Methodology Adopted

The DSAS(Digital shoreline analysis system) begins with the work of construction coast line and baseline. Transects are used on formation basis of DSAS, by studying changes along the coast along Cuddalore coast to the coast of
Nagapattinam till kodiyakarai. The EPR is calculated by dividing maritime distance in the past between the old and young coast and the NSM is calculated to find the total range of variability in terms of average rate. These transformations are calculated by drawing the base and calculating the distance between the coast. On the basis of the shoreline, erosion is calculated by orthoganal transects along the coast. Erosion findings and accretion rates for Cuddalore to Nagapattinam were divided into five main categories, high erosion / accretion, and stable areas in Cuddalore to the Nagapattinam district coast

\section{RESULTS}

Shoreline transformation analysis was attempted to calculate the number of coastal shifts from the time series of most coastline positions. The coastline change map presented in figures (fig 3,4) shows the shoreline change map according to Shoreline classification, erosion and accretion respectively. The results obtained from the analysis of shoreline changes in the forms of integers, where positive $(+)$ integers indicate for accretion and negative(-) indicates for erosion, Further the length of shoreline changes in kilometers for Cuddalore to Nagapattinam was calculated. From the Study area (CUDDALORE TO NAGAPATTINAM) ,The total coast line from Cuddalore to Nagapattinam till kodiyakarai is 176.65 kilometers, Maximum Erosion occured in this study area at the rate of $-10.42 \mathrm{~m}$, Minimum of $-1.7 \mathrm{~m}$ at the average of $-2.11 \mathrm{~m}$ and Maximum accretion rate of $60.61 \mathrm{~m}$ and Minimum Accretion of $2.01 \mathrm{~m}$ and average rate of accretion in this study area (cuddalore to nagapattinam) are $3.52 \mathrm{~m}$, The Total classification for shoreline change status for cuddalore to nagapattinam is 24.45 of shoreline Changes (Erosion)in Kilometers and 73.2 $\mathrm{km}$ (Accretion)of Shoreline changes in kilometer during the last seventeen years, Maximum erosion occurred in the Mayiladuthurai district, Tharangambadi and northern part of Chidambaram region, Karaikal region and between Nagapattinam \& Velanganni closer to Vedaranyam coast ,since it is a Straight- shoreline(flat shoreline) it has been easily affected by erosion and accretion. Thrangambadi to Nagore beach have been highly affected during the last 17 years.From this study that the rate of classification for the study area (zone wise) for the last 17 years, understood that the very high erosion occurred at the rate of (-10.02 to $5.0 \mathrm{~m})$ and very high accretion rate of (7.41 to $60.6 \mathrm{~m})$,High erosion at the rate of (-5.01 to $2.0 \mathrm{~m})$, stable of (-2.01 to $1 \mathrm{~m})$ and high accretion of (1.01 to $7.4 \mathrm{~m}$ )in the Cuddalore to Nagapattinam coast between the year 2003-2017. Stable Coast between Cuddalore to Nagapattinam is fifty five(55) kilometers. Very high erosion of (3.5 kilometer) change in shoreline, High erosion of (20.5 kilometer) in Chidambaram region change in shoreline and high accretion of (86.2 kilometer) changes in shoreline. Very high accretion of (6.3 kilometer) change in shoreline during the time period of 2013-2017(cuddalore to nagapattinam)

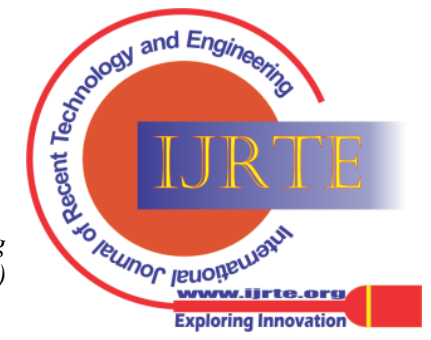



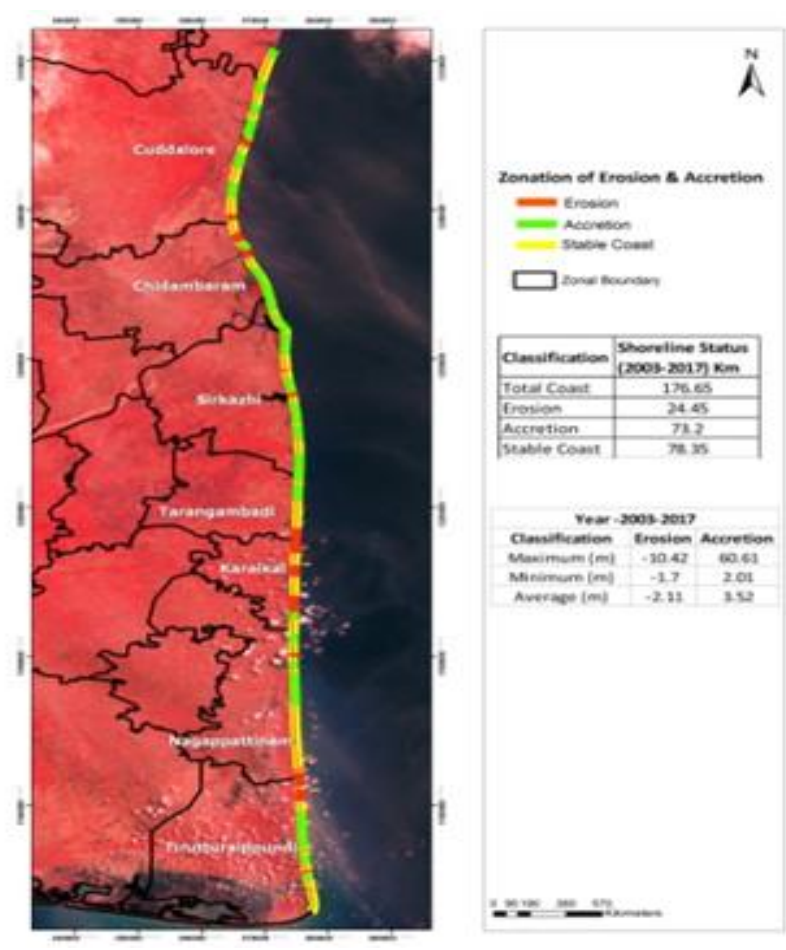

Fig.3 Shoreline Change Map

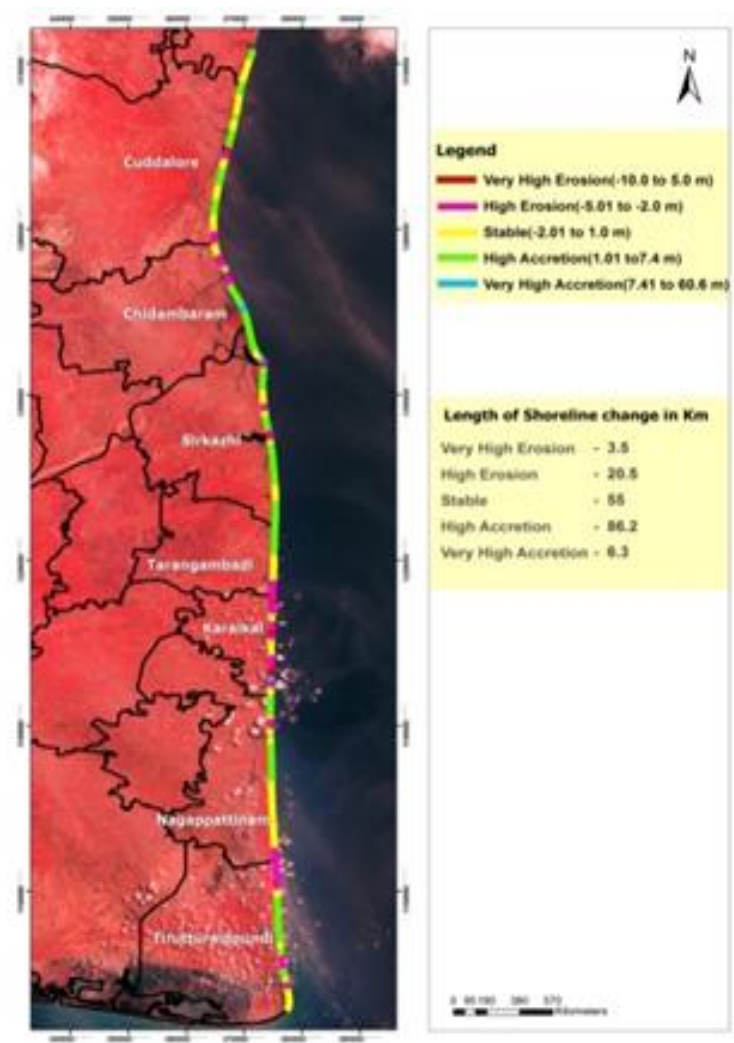

Fig.4 Erosion and Accretion changes area

\section{A. shoreline change with respect to epr:}

The minimum required data sets EPR are two shorelines over a period of 2003 to 2017 (2003 and 2017) time to compute shoreline movement,this approach is adopted to integrate the coastline shift rates by dividing the interval of shoreline movement.
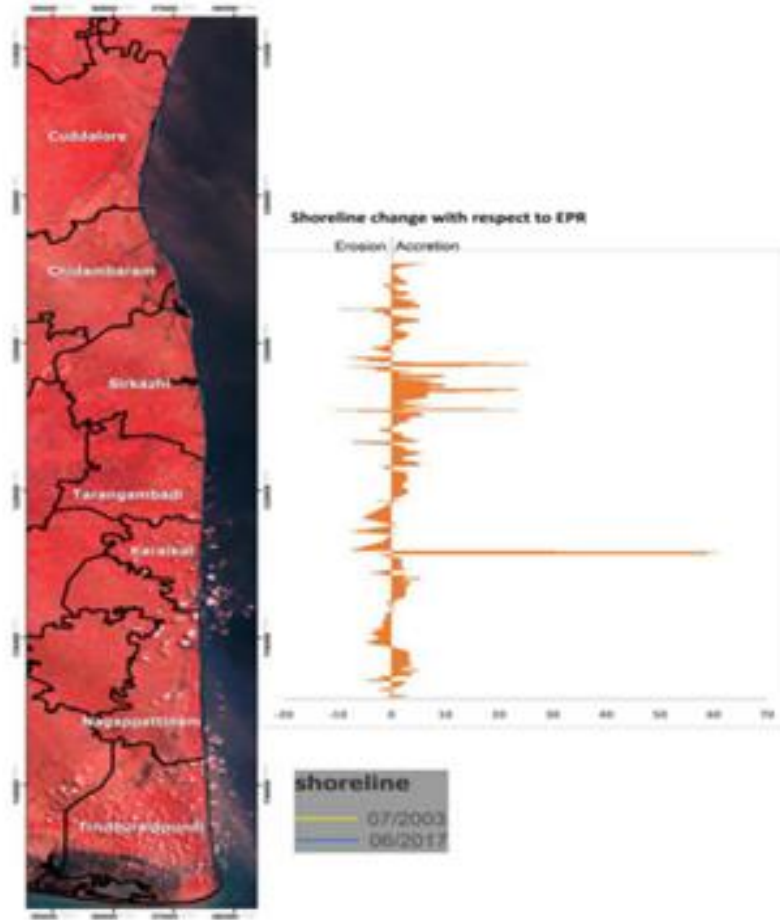

Fig.5 Shoreline change map with respect to EPR

\section{B. Shoreline change with respect to nsm:}

The coastline of the network shows the distance associated with the two dates of the previous roll reporting the distance between the old and young shorelines and therefore results in End point rate.

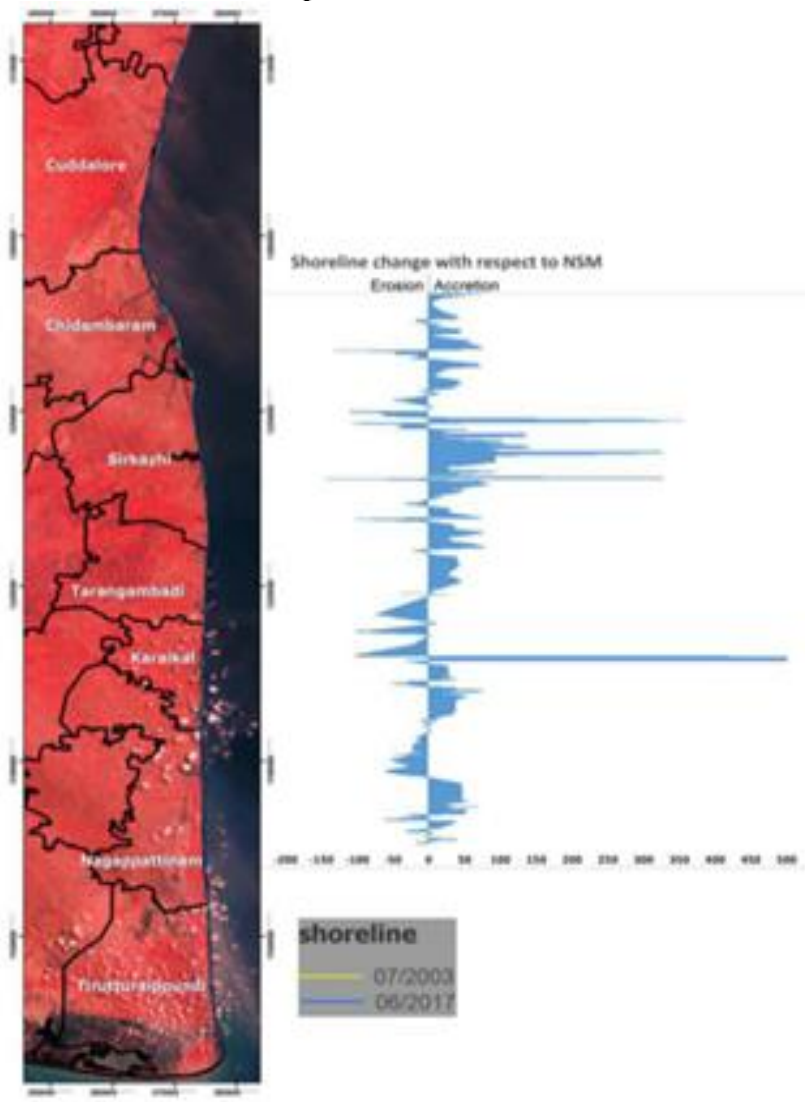

Fig 6 Shoreline change map with respect to NSM

Blue Eyes Intelligence Engineering and Sciences Publication (BEIESP)

(C) Copyright: All rights reserved.

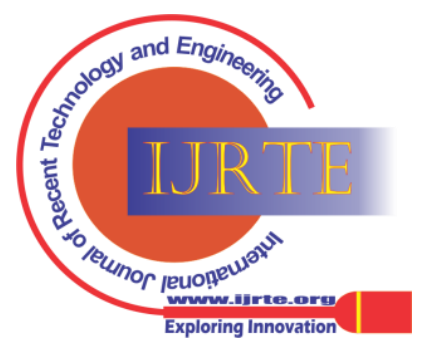




\section{CONCLUSION}

Remote sensing and DSAS statistical methods are useful in guiding long-term coastal change provides an outlook of erosion and coastal pattern accretion of coastal areas. From the study (2003 to 2017) high- places have been damaged by a severe storm, tsunami and other natural disasters The study confirms the significant erosion in the northern region of Chidambaram, Karaikal region and between Nagapattinam and Velankganni especially from Tharangambadi beach to Nagore beach.. Stable coast between Cuddalore to Nagapattinam is $55 \mathrm{~km}$, very high of $(3.5 \mathrm{~km})$ change lines on the coast, high erosion of $(20.5 \mathrm{~km})$ change lines on the coast and high accretion of $(86.2 \mathrm{~km})$ change lines on the coast, Very high accretion of $(6.3 \mathrm{~km})$ change lines on the coast. Coastline change Monitoring of the coast is important in monitor changes in the near future. The coastal changes found in this study are beneficial to coastal management, staying cost-effective to manage the coast and to protect its environment and coastal resources especially mangrove forest .

\section{REFERENCES}

1. Usha Natesan et,al., “ Monitoring Longterm Shoreline Changes Along Tamil Nadu Coast ,India by using Geospatial techniques (2015),vol.4,pp 325-332

2. Karim Nassar et,al ., " Shoreline change Analysis Detection using DSAS"- marine Georesources technology (2018)

3. Ramasamy Karikalan and Thangaraj" Assessment of ShorelineChange detection works on Cuddalore, Nagapattinam Coast Tamil Nadu, (India) using Geospatial Techniques Department of Zoology at Alagappa University (2019) vol.12(2)

4. Maheshwaran et,al , " Shoreline detection of Nagapatinam coast by utilizing geospatial techniques published International Journal of Geomatics ,Geosciences ( 2015),vol.5,no: 4

5. Salghunaa N.N. and Aravind Bharathvaja, " Shoreline Change Analysis For Northern Part of Coromandel shore", Int-national Conference on Water Resources, 4(2015), 317 - 324

6. Murali, R. M., R. Dhiman, R. Choudhary, J. K. Seelam, D. Ilangovan,P.Vethamony., " Decadal Shoreline Assesment using Remote Sensing along the side of Central Odisha coast, India from Environmental Earth Sciences (2015) 74 (10):7201-13

7. K.Deepthi ,K.Kathiravan, Usha Natesan,N.Thulasiraman., "Shoreline Change analysis of Vedarnyam Coast" Environ Monit Asses (2013) 185:5099-5109

8. P.Sheik Mujabar, N.Chandrasekar., "Shoreline change analysis along the coast between Kanyakumari and Tuticorin of India using Remote Sensing and GIS" (2013) 6:647-664

9. Manik Mahapatra, R.Ratheesh,A.S Rajawat., "Shoreline change analysis along the coast of South Gujarat,India,Using Digital Shoreline Analysis System"(December 2014) ,42(4):869-876

10. Kannan R, Ramanamurthy MV and Kanungo A., "Shoreline change monitoring in Nellore coast at East coast Andhra Pradesh district using Remote Sensing and GIS published Journal of Fisheries and Livestock production" (2016), 4:1

\section{AUTHORS PROFILE}

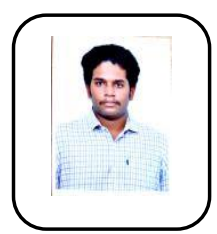

Pradeep Jeganathan Graduated in Electronics and Communication Engineering in Velammal Institute of Technology,Ponneri and completed Masters in Remote Sensing and Geographical Information System in SRM Institute of Science and Technology, Kattankulathur (formerly known as SRM University)

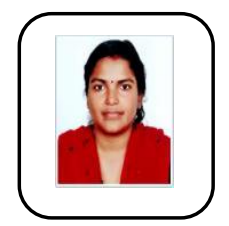

Dr. Aparna S. Bhaskar, (Ph.D) Associate Professor, Department of Civil Engineering, Kattankulathur Campus, SRM Institute of Science and Technology(formerly known as SRM University)

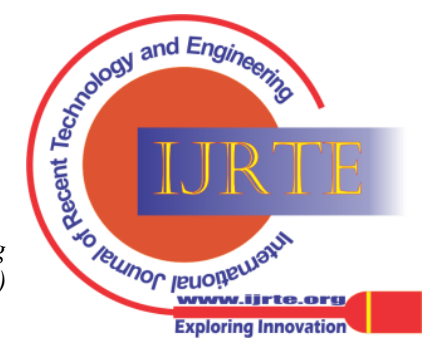

